\title{
Study on confirmation of water right in Yangyuan County, China
}

\author{
Meng Zeng ${ }^{1,2}$, Meiyu Liu ${ }^{1,2}$, Aixi Gong ${ }^{3, a}$, Weici Quan ${ }^{1,2}$ and Zihao Man ${ }^{1,2}$ \\ ${ }^{1}$ School of water conservancy and Hydropower Engineering, Hebei University of Engineering, Handan, Hebei, China \\ ${ }^{2}$ Hebei Research Center for water ecological civilization and social governance, Handan, Hebei, China \\ ${ }^{3}$ Hebei Extension center of water resources research and hydrological technology experiment, Shijiazhuang Hebei, China
}

\begin{abstract}
In order to implement the reform of the water resources fee in Hebei Province, the right confirmation of water resources use is crucial. In this study, Yangyuan County of Zhangjiakou, Hebei Province was selected for the research and the regional situations of hydrology, social economy, water conservancy project distribution and water supply were analyzed. Then, rights of residential water use, industrial water use, ecological water use, reserve water amount and agricultural water use in study region were calculated. Furthermore, the corresponding scheme of water use rights was confirmed. The results could provide technical support to the optimization of water resources management for Yangyuan County and reference to other regions of Hebei Province.
\end{abstract}

\section{Introduction}

Water is the source of life and a crucial strategic resource for economic development and human society survival. The principles of water resource use were clearly interpreted in Water Law of the People's Republic of China, which include the state-owned attribution, water license application for use, water resources fees payment and water rights obtaining. According to the related stipulation, it is evident that water right is a benefit right for who use based on the public ownership principle of water resources [1]. Therefore, local water authorities or river basin management organization should confirm and identify water right for the spatial scope of water resources in the region/river basin, in order to distinguish the ownership right and use right of water resources, and identified water quantity. Based on the confirmation of water right, the attribution relationship of water rights, the related interests and obligations should be clarified ${ }^{[2]}$, which is as the basis principle of rational water price delimiting and aiming to improve the regulations of water rights market would ${ }^{[3-4]}$.

In this research, Yangyuan County of Hebei Province, China was selected as the study area and the water rights of all walks of life in this region were calculated and identified. This research should be beneficial to practicing the Most Stringent Water Resources Management in Yangyuan County, perfect the regulation of water resources tax, improve the efficiency of local water resources management, and promote local sustainable development.

\section{Study area}

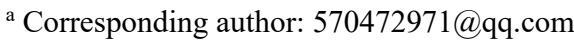

Yangyuan Country is located in the northwest of Hebei Province (Figure 1) and belongs to Yongding River basin in the Haihe River Basin. In this county, the average frost-free period is 136 days, the annual rainfall is $371 \mathrm{~mm}$, the average transit runoff volume is 481 million $\mathrm{m}^{3} / \mathrm{y}$, the available flood volume is 36.26 million $\mathrm{m}^{3}$, and the groundwater storage is about 76.36 million $\mathrm{m}^{3}$.

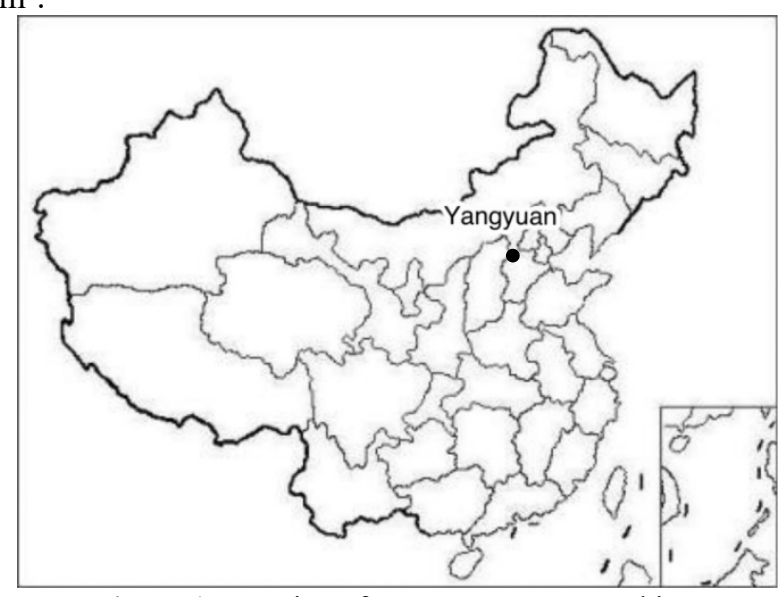

Figure 1. Location of Yangyuan County, China.

\section{Scheme of water right confirmation}

\subsection{Confirmation of total permitted volume}

The water right confirmation calculates the water consumption of varies industries in the region mainly based on determining distributable water amount, which is the first premise of the whole scheme of water right confirmation, and is also the key to implement the most stringent water resources management system and groundwater pressure recovery management. Based on 
the analysis of various water sources such as shallow groundwater, local surface water and extraterritorial water diversion ${ }^{[5]}$, The water amount is at the approved interface of water rights after deducting the loss of available water amount in region. As shown in formula (1):

$$
W_{i d}=W_{i u} \times\left(1-\alpha_{i}\right)
$$

Where $W_{i d}, W_{i u}$ and $a_{i}$ represent the distributable water amount, available water amount and loss coefficient of type $\mathrm{i}$ water resources in the region. Among them, the regional self-produced surface water resource is determined according to the second water resources evaluation and other existing results. The loss coefficient is based on consulting the statistical yearbook of water conservancy and related data, supplemented by field visits to investigate the status of local water conservancy projects and evaporation, leakage losses and other comprehensive determination. In order to implement the Most Stringent Water Resources Management System and comprehensive groundwater treatment, the regional total red line and the exploitable groundwater red line are taken as the constraints of the total amount of distributable water and the distributable amount of shallow groundwater respectively, so as to achieve the goal of sustainable development. It should be noted that, in order to comply with the relevant provisions of comprehensive control of groundwater overexploitation in Hebei Province, the right of groundwater does not include the deep groundwater. In the future, with the increase of water-saving measures and the reform, expansion and construction of surface water projects, the use of deep groundwater will be gradually reduced and banned.

\subsection{Determination of distributable water}

The determination of water consumption in various industries is the core content of the plan of water rights confirmation. Based on the "Hebei Province Water Right Registration Method", the validity period of water rights is from 2018 to 2020; the calculation takes 2016 as the base year, and the average value of the relevant data from 2014 to 2016 is analyzed. Among them, the domestic water consumption amount is checked by per capita water consumption and water users, see formula (2); the amount of non-agricultural production water consumption is the sum of the reasonable water consumption of local water-using enterprises of various scales, see formula (3); the amount of ecological environment water consumption is checked and approved according to greening irrigation and road spraying water respectively, see formula (4). In view of the annual growth of population and water saving; it is also necessary to verify and reserve a certain amount of water according to the local water supply and demand analysis to ensure the demand for domestic and ecological water. The amount of agricultural distributable water is calculated by the total amount of distributable water in the county deducts the reasonable amount of domestic, non-agricultural, ecological and reserved water, see formula (5).And then the average water volume per mu can be obtained, see formula (6). It is worth emphasizing that the water consumption of all the units allocated above must meet the local water quota. The above formulas are as follows:

$$
\begin{gathered}
W_{d}=W_{p} \times S \\
W_{n}=\sum W_{e} \\
W_{e}{ }^{\prime}=W_{g}+W_{r} \\
W_{a}=W-W_{d}-W_{n}-W_{e}{ }^{\prime}-W_{r}{ }^{\prime} \\
W_{m}=W_{a} / A
\end{gathered}
$$

Where $W_{d}, W_{p}$ and $S$ means domestic water consumption, per capita water consumption and water consumption population respectively; $W_{n}$ and $W_{e}$ respectively represent water consumption of nonagricultural production and rational water consumption of water enterprises; $W_{e}$, $W_{g}$ and $W_{r}$ respectively represent ecological water consumption, green irrigation water consumption and road spraying water consumption; $W_{a}, W$ and $W_{r}$ ' represent agricultural water consumption, total distributable water consumption and reserved water consumption respectively; $W_{m}$ and $A$ represent the amount of water per mu and the effective irrigation area respectively.

\section{Case study in Yangyuan County}

\subsection{Determination of distributable water}

According to "Zhangjiakou City Water Resources Assessment Report (2005.11) ", the exploitable amount of shallow groundwater of Yangyuan County is 48.82 million $\mathrm{m}^{3}$, which is larger than 28.3 million $\mathrm{m}^{3}$ of the "Three Red Lines" of groundwater control index in Yangyuan County. Therefore, the distributable amount of shallow groundwater should be determined according to the red line index. The surface water available capacity is 16.253 million $\mathrm{m}^{3}$, the loss coefficient is 0.3 , and the calculated loss is 4.8759 million $\mathrm{m}^{3}$ to the bucket and canal mouth or the water-raising point. So the distributable water amount is 11.3771 million $\mathrm{m}^{3}$.The distributable water total amount is the sum of shallow groundwater and local surface water, totaling 39.6771 million $\mathrm{m}^{3}$, which is less than the total control index of the "Three Red Lines" of 44.12 million $\mathrm{m}^{3}$. The distributable water is shown in Table 1.

\subsection{Water allocation in different sectors}

On the basis of rationally checking and verifying the amount of water for living, non-agricultural production, ecological use and reserved water, the distributable water for agriculture is determined. The total amount of distributable water for the whole county is distributed to all sectors.

Table 1. Statistics of distributable water in Yangyuan County

\begin{tabular}{|c|c|c|c|}
\hline \multirow{3}{*}{ Type } & $\begin{array}{c}\text { Surface } \\
\text { water } \\
\left(\mathbf{1 0}^{4} \mathbf{m}^{\mathbf{3}}\right)\end{array}$ & $\begin{array}{c}\text { Shallow } \\
\text { groundwater } \\
\left(\mathbf{1 0}^{4} \mathbf{m}^{\mathbf{3}}\right)\end{array}$ & $\begin{array}{c}\text { total water } \\
\text { volume } \\
\left(\mathbf{1 0}^{4} \mathbf{m}^{\mathbf{3}}\right)\end{array}$ \\
\hline
\end{tabular}




\begin{tabular}{|c|c|c|c|}
\hline $\begin{array}{c}\text { Available } \\
\text { amount }\end{array}$ & 1625.3 & 2830 & 4455.3 \\
\hline Loss amount & 487.59 & 0 & 487.59 \\
\hline $\begin{array}{c}\text { Distributable } \\
\text { water volume }\end{array}$ & 1137.71 & 2830 & 3967.71 \\
\hline
\end{tabular}

\subsubsection{Verification of domestic water consumption}

\subsubsection{1 verification of water consumption in cities and towns}

Urban domestic water use includes urban public water use and residential water use. Yangyuan County adopts centralized water supply mode, and the water supply source is shallow groundwater.

From 2014 to 2016, according to the Yangyuan County Water Resources Bulletin, the urban domestic water consumption was 1.008 million $\mathrm{m}^{3}, 3.053$ million $\mathrm{m}^{3}$, and 3.763 million $\mathrm{m}^{3}$ respectively, with an average value of 2.608 million $\mathrm{m}^{3}$. The water use population was 80.4 thousand, 81.2 thousand and 90.6 thousand, with an average value of 84.1 thousand. According to the field investigation and the service life survey of the pipeline in Yangyuan County, The leakage coefficient of the network pipe is $15 \%$. Convert the amount of water lost to water consumption of users and the average water consumption per capita in the last three years is $29.2 \mathrm{~L} / \mathrm{P} \bullet \mathrm{d}, 87.56 \mathrm{~L} / \mathrm{P} \bullet \mathrm{d}$ and $96.72 \mathrm{~L} / \mathrm{P} \bullet \mathrm{d}$, respectively. In view of the fact that the Yangyuan urban pipeline network has not been reconstructed and expanded in 2014 , its per capita water consumption is low and does not conform to the existing level of urban domestic water consumption, so the water consumption per capita of this year is not included. On the basis of the water consumption average in 2015 and 2016 (92.14 L / P•d), considering the gradual improvement of regional living standards in the future and the implementation of watersaving measures, the per capita domestic water consumption is finally approved to be $90 \mathrm{~L} / \mathrm{P} \cdot \mathrm{d}$. According to the population growth rate of urban residents in Yangyuan County in the past three years, it is estimated that the average population in the validity period of water rights is 91.1thousand, then the reasonable water consumption for urban life is $819.9 \mathrm{~L} / \mathrm{d}$, and the reasonable water consumption for urban life is 2.9926 million $\mathrm{m}^{3}$ totally in a year. See Table 2 for details.

Table 2. check list of urban living water in Yangyuan County.

\begin{tabular}{|c|c|c|c|c|c|}
\hline Category & $\begin{array}{c}\text { Water } \\
\text { consumption } \\
\left(\mathbf{1 0}^{\mathbf{4}} \mathbf{m}^{\mathbf{3}} \mathbf{)}\right.\end{array}$ & $\begin{array}{c}\text { Population } \\
\mathbf{( 1 0}^{\mathbf{4}} \mathbf{n}\end{array}$ & $\begin{array}{c}\text { Per capita water } \\
\text { consumption } \\
(\mathrm{L} / \mathrm{P} \cdot \mathrm{d})\end{array}$ & $\begin{array}{c}\text { Quota } \\
(\mathrm{L} / \mathrm{P} \cdot \mathrm{d})\end{array}$ & $\begin{array}{c}\text { Reasonable } \\
\text { judgement }\end{array}$ \\
\hline 2014 & 100.8 & 8.04 & 29.20 & Unreasonable \\
\hline 2015 & 305.3 & 8.12 & 87.56 & \multirow{2}{*}{$50 \sim 140$} & Reasonable \\
\hline 2016 & 376.3 & 9.06 & 96.72 & \\
\hline Average & 340.8 & 8.59 & 92.39 & & \\
\hline Approved value & 299.26 & 9.11 & 90 & & \\
\hline
\end{tabular}

\subsubsection{2 verification of rural domestic water consumption}

In the current year, the total population of rural water supply in Yangyuan County is 184.4 thousand, and the water supply source is also shallow groundwater. From 2014 to 2016, the rural domestic water consumption was 4.037 million $\mathrm{m}^{3}, 2.085$ million $\mathrm{m}^{3}$ and 2.405 million $\mathrm{m}^{3}$, with an average of 2.245 million $\mathrm{m}^{3}$; the water consumption population was 196 thousand, 194.8 thousand and 184.4 thousand, with an average of 189.6 thousand; the average water consumption per capita was
$56.43 \mathrm{~L} / \mathrm{P} \bullet \mathrm{d}, 29.32 \mathrm{~L} / \mathrm{P} \bullet \mathrm{d}, 35.73 \mathrm{~L} / \mathrm{P} \bullet \mathrm{d}$, with a three-year average of $32.44 \mathrm{~L} / \mathrm{P} \cdot \mathrm{d}$.

As the level of rural domestic water use in Yangyuan County is gradually improving, the average water consumption per capita in rural areas is $35 \mathrm{~L} / \mathrm{P} \bullet \mathrm{d}$. In the validity period of the water right based on the three-year average; the rural population is calculated according to the average annual growth rate of nearly three years, and is approved as 185.5 thousand. Finally, the rational water consumption in rural areas is approved as 2.37 million $\mathrm{m}^{3}$. See Table 3 for details.

Table 3. check list of rural living water in Yangyuan County.

\begin{tabular}{|c|c|c|c|c|c|}
\hline Category & $\begin{array}{c}\text { Water } \\
\text { consumption } \\
\left(\mathbf{1 0}^{\mathbf{4}} \mathbf{m}^{\mathbf{3}}\right)\end{array}$ & $\begin{array}{c}\text { Population } \\
\mathbf{( 1 0}^{\mathbf{4}} \mathbf{)}\end{array}$ & $\begin{array}{c}\text { Per capita water } \\
\text { consumption } \\
(\mathrm{L} / \mathrm{P} \bullet \mathrm{d})\end{array}$ & $\begin{array}{c}\text { Quota } \\
(\mathrm{L} / \mathrm{P} \bullet \mathrm{d})\end{array}$ & $\begin{array}{c}\text { Reasonable } \\
\text { judgement }\end{array}$ \\
\hline 2014 & 403.70 & 19.60 & 56.43 & & Reasonable \\
\hline 2015 & 208.50 & 19.48 & 29.32 & Reasonable \\
\hline 2016 & 240.50 & 18.44 & 35.73 & \multirow{3}{*}{$30 \sim 60$} & Reasonable \\
\hline Average & 224.50 & 18.96 & 32.44 & & Reasonable \\
\hline Approved value & 237 & 18.55 & 35 & & \\
\hline
\end{tabular}

\subsubsection{3 approved total domestic water consumption}

The domestic water consumption in Yangyuan County is the sum of the reasonable water consumption in cities and towns and rural areas, is finally approved as 5.3626 million $\mathrm{m}^{3}$. 
The rational water consumption of enterprises in Yangyuan County is approved on the basis of investigation and analysis the rationality of the annual average water consumption of enterprises in the past three years. According to the investigation, there are 4 water-using enterprises in the county consume water with more than 1 thousand $\mathrm{m}^{3}$ with water intake licenses, and the average annual water consumption of these enterprises is 3.38 million $\mathrm{m}^{3}$, the water source is shallow surface water. In addition, small and micro enterprises with less water consumption in cities and towns mainly use domestic water, which is supplied by local centralized water supply network, so it is no longer included in non-agricultural production water.

\subsubsection{Verification of ecological water consumption}

The ecological water consumption of Yangyuan County mainly includes greening irrigation water and road spraying water. According to the data of "Yangyuan County Water Resources Bulletin" from 2014 to 2016, and combined with the actual investigation of the current situation, the annual average water consumption of ecological environment in Yangyuan County is 193 thousand $\mathrm{m}^{3}$, including 100 thousand $\mathrm{m}^{3}$ for greening irrigation with $0.25 \mathrm{~km}^{2}$, 93 thousand $\mathrm{m}^{3}$ for road spraying with $0.105 \mathrm{~km}^{2}$. In this case, the average value of water consumption in the whole county is adopted, which is 193 thousand $\mathrm{m}^{3}$. According to the principle of unconventional water utilization priority, reclaimed water is used as the source of water for ecological environment. The reclaimed water amount in Yangyuan County is 876 thousand $\mathrm{m}^{3}$, which can obviously meet the demand of ecological water consumption. Therefore, the amount of ecological water consumption is no longer included in the total index of conventional water distribution.

\subsubsection{Verification of reserved water volume}

In order to ensure the growth of water demand for basic living and ecological environment within the validity period of water right, the reserved water needs to be verified by water resources supply and demand analysis. According to the analysis of supply and demand, the increment of domestic water demand and ecological water demand during the validity period of water right in Yangyuan County are 621.1 thousand $\mathrm{m}^{3}$ and 34.7 thousand $\mathrm{m}^{3}$ respectively. It can be seen from above that the source of water supply in Yangyuan County is shallow groundwater, and the increment of ecological water demand is guaranteed by reclaimed water. As the source of water supply for all trades does not change during the validity period of water rights, the increment of ecological water demand is no longer reserved, but only reserved for the increment of domestic water demand. In summary, the area reserved water is approved to be 621.1 thousand $\mathrm{m}^{3}$.

\subsubsection{Verification of agricultural water consumption}

Agricultural distributable water, is the total amount of distributable water in the county after deducting reasonable living, non-agricultural production and reserving distributable water, and is also the local surface water and surplus shallow groundwater. According to the calculation of tables 1-3, 1893.63 million $\mathrm{m}^{3}$ of shallow groundwater and 11.3771 million $\mathrm{m}^{3}$ of local surface water are available for agriculture, which is 30.3134 million $\mathrm{m}^{3}$.

Table 4. calculation results of agricultural distributive water

\begin{tabular}{|c|c|c|}
\hline $\begin{array}{c}|c| \\
\text { Local surface } \\
\text { water } \\
\left(\mathbf{( 1 0}^{\mathbf{4}} \mathbf{m}^{\mathbf{3}}\right)\end{array}$ & $\begin{array}{c}\text { Solume } \\
\text { groundow } \\
\left(\mathbf{1 0}^{\mathbf{4}} \mathbf{m}^{\mathbf{3}}\right)\end{array}$ & $\begin{array}{c}\text { Total } \\
\left(\mathbf{1 0}^{\mathbf{4}} \mathbf{m}^{\mathbf{3}}\right)\end{array}$ \\
\hline 1137.71 & 1893.63 & 3031.34 \\
\hline
\end{tabular}

In summary, the water amount and water source types of all trades in Yangyuan County have been calculated and approved. The specific distribution process is shown in Figure 2.

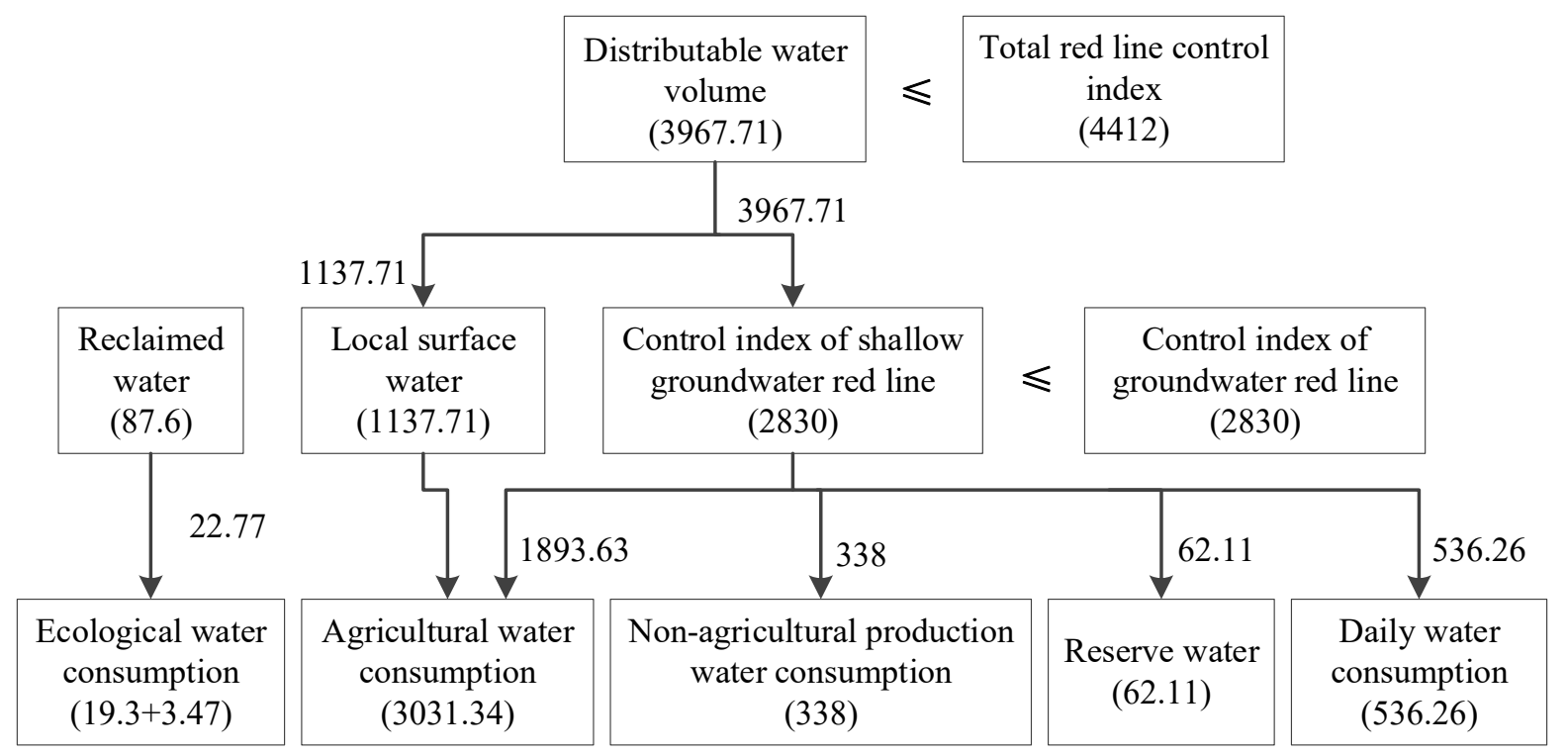

Figure 2. Results of water allocation in Yangyuan County. $\left(10^{4} \mathrm{~m}^{3}\right)$ 


\subsection{Feasibility analysis of the scheme}

\subsubsection{Reasonableness analysis of distribution method and result}

Taking 2016 as the base year, the actual water consumption from 2014 to 2016 as the basic data of water consumption, after making a reasonable analysis, the rational water consumption in all sectors is confirmed. The urban and rural domestic water consumption in the scheme was approved as $90 \mathrm{~L} / \mathrm{P} \bullet \mathrm{d}$ and $35 \mathrm{~L} / \mathrm{P} \bullet \mathrm{d}$ respectively, which meet the quota values of $50 \sim 140 \mathrm{~L} / \mathrm{P} \cdot \mathrm{d}$ and $30 \sim 60 \mathrm{~L} / \mathrm{P} \bullet \mathrm{d}$ in the Water Quota of Hebei Province (Table 2 and Table 3). The water consumption for non-agricultural production is authorized to be 3.38 million $\mathrm{m}^{3}$, also meet the scope of the Water Consumption Quota of Hebei Province. The ecological water consumption is the sum of the green irrigation water consumption and the road spraying water consumption, and the water supply source is reclaimed water, which is not included in the water right distribution. In the reserved water analysis, the average water consumption from 2014 to 2016 is taken as a reference, and the water resources supply and demand are analyzed and approved. Considering the great potential of agricultural water saving, the final allocation of agricultural water is considered as the total amount of distributable water in the county after deducting reasonable urban life, non-agricultural production and reserving distributable water. Furthermore, dividing the determined agricultural water consumption by the effective cultivated land area of the whole county, the average water consumption per mu in the region is 106 $\mathrm{m}^{3}$, which also meets the Quota.

To sum up, the scheme allocation method is reasonable, the quota of various industries related to water rights allocation meets the Water Quota of Hebei Province, so the scheme meets the requirements of "Hebei Province Water Rights Registration Method".

\subsubsection{Analysis of the implementation of "Three Red Lines" indicators}

The rationality of the water consumption of the present water users is fully analyzed. The water allocation can not only meet the current water demand, but also meet the quota requirements. During the validity period of water rights, the growth demand of domestic water can be met by reserved water, the growth demand of ecological water can be met by renewable water, and the growth demand of non-agricultural water can be met by the transfer of water rights and the use of unconventional water. Therefore, domestic, non-agricultural and ecological water allocation not only meets the current water demand, but also meets the future water demand, and the data of water allocation is reasonable.

\subsubsection{Influence analysis of water rights allocation}

The scheme for life, non-agricultural production and ecological water right is based on a full analysis of the rationality of water consumption and current water use in the past three years from 2014 to 2016. The water allocation of all sectors can meet the demand for water use growth in the current water use and the validity period of water right. It not only respects the reality but also considers the future development.

It is pointed out that although the amount of water allocated by agricultural water rights is less than that of the present situation, the normal agricultural water consumption can still be maintained through the implementation of water-saving irrigation, rational use of unconventional water and water right transfer measures. In extremely low water years, the regulation function of groundwater for many years can be utilized to allow a small amount of groundwater to be overexploited to meet the water demand of agricultural production. Therefore, this scheme can not only curb groundwater overdraft but also can't affect agricultural production and food security. So, the implementation of this program has a very low risk of negative impact on residents' lives, non-agricultural production and ecological environment.

\section{CONCLUSION AND PROSPECT}

Based on the analysis of the rationality of the current water consumption in Yangyuan County, China from 2014 to 2016, this study calculates and confirms the water rights of regional life, non-agricultural production and ecology. The results show that the approved water rights for living, non-agricultural, reserved and agricultural use are 5.3626 million $\mathrm{m}^{3}$ and 3.38 million $\mathrm{m}^{3}, 621.1$ thousand $\mathrm{m}^{3}$ and 30.3134 million $\mathrm{m}^{3}$ respectively.; and ecological water can be satisfied by reclaimed water. The scheme has passed the feasibility analysis, and the calculation shows that the unit water consumption involved in water rights allocation meets the requirements of Hebei Provincial Water Quota, which shows the rationality of the scheme. The research results can provide decision support for regional water resources management.

In the future, the implementation of water right needs the full cooperation of the government to solve the various contradictions and interests disputes in the implementation process; in particular, the county government should coordinate cooperation, scientific distribution, to maximize the mobilization of the enthusiasm of all staffs to ensure the smooth implementation of the water rights distribution program.

\section{Acknowledgement}

The researchers would like to extend their thanks to the National Natural Science Foundation of China (grant No. 51879066) and the Key Project of Humanities and Social 
Sciences Research of Hebei Education Authority (grand No. ZD201443).

\section{Reference}

1. H.Li, J.Zhao, The Principle of Initial Water Rights Distribution and Its Quantitative Method [J]. Journal of Applied Basis and Engineering Science. Supplement: 8-14. (2005).

2. T.Li, H.Dong, L.Xu, Exploration and Research on water rights confirmation in Qing'an County, Heilongjiang Province [J].Water-saving irrigation., 08:106-109. (2017).

3. S.Qin, Discussion on water rights system and initial water rights allocation [D]. Hohai University. (2005).

4. Z.Wang, Study on water rights system [D]. Shandong University. (2008).

5. B.Zhang, C.Chen, R.Shang, Exploration and practice of water rights affirmation in Hebei Province [J].China Water Conservancy, S: 3-14. (2015).

6. N.Hu, A.Gong, R.Shang, Distribution method of water rights in groundwater overexploitation area and case analysis [J]. Groundwater, 37 (4): 57-58. (2015) 